\title{
PENAL MEDIATION OF TREATMENTS FOR CHILDREN IN THE JUVENILE JUSTICE SYSTEM
}

\author{
Irma Cahyaningtyas \\ Faculty of Law Diponegoro University, Semarang, Central Java \\ irmafjr83@gmail.com
}

\begin{abstract}
The protection of children becomes the responsibility of all parties, namely family, community and government. Indonesia through the Act No. 11 Year 2012 on Juvenile Justice System provides protection namely diversion which should be emphasized as a penal mediation which can be used to solve a juvenile cases. There are two main problems; firstly, how is the penal mediation process in the juvenile justice system; secondly, how is the implementation of the penal mediation which is based on Pancasila?

The research method used in this paper was normative juridical research method. The approach used in this study is socio legal approach and the data analysis method used a qualitative analysis.

The results that in penal mediation in the juvenile cases namely diversion aims to achieve restorative justice. The diversion process is very important and must involve the parties in order the mediation be effective. This process is what distinguishes from the treatments of juvenile's cases before Act No. 11 Year 2012. In the previous times, penal mediation was not acknowledged so law enforcement procedure is always ends at Juvenile court.

Penal mediation in juvenile justice system must be based on Pancasila as the philosophical foundation of Indonesia, which means diversion process must be in accordance with the values of Pancasila, which are are religious moral values; humanistic values; nationalistic values, democratic, and social justice.
\end{abstract}

Keywords: Penal mediation, juvenile justice system

\section{Introduction}

The children's existence needs protection from all parties, namely parents, society, and government. The Preamble to the Constitution of the Republic of Indonesia Year 1945 paragraph 4 asserts that the national goals of Indonesia are to protect all the people of Indonesia and the entire land in Indonesia, to promote the general welfare, to enrich the life of a nation, and to participate in the establishment of world order based on freedom, lasting peace and social justice.

The development of era and technology brings negative and positive effects for children. The negative effects on children encourage them to act naughty and infringe the provision in the law. This problem can make children must deal with the law.

Internationally admit that the aims of juvenile justice system stated in the Resolution of UN Assembly No.40/32 on 29 November 1985 concerning United Nations Standard Minimum Rules for Administration of Juvenile Justice (The Beijing Rules) which the aims of juvenile justice system is to promote the well being of the juvenile and the principle of proportionality. The aims to promote 
the well being of the juvenile is the main focus and for those reasons, the principle of juvenile justice is to avoid the merely punitive sanction. The aims of principle of proportionality because of merely expressed in the terms of balancing between the offence and the sanction.

The policy of punitive sanction to the juvenile shows that it has tendency to harm the development of the children. This tendency has the negative effect in the process of juvenile justice system and cause stigma to the children. To avoid those kind of effect and stigma (labeling) to the juvenile, United Nation Standard Minimum Rules for Administration of Juvenile Justice (The Beijing Rules) give the authority to the law enforcer to handle and solve the problems without using the formal way by stopping the process or sending the juvenile to the society and other social service. Those kinds of policy namely as diversion which is transferring the investigation as stated in Rule 11.1, 11.2 and 17.4 ("The Beijing Rules").

In Indonesia, the government has issued the policies on efforts to protect children through the valid legislation. The legislation includes Act No. 4 Year 1979 on the Prosperity of Children, Act No. 11 Year 2012 on Juvenile Justice System, and Act No. 23 Year 2002 in conjunction with Act No. 35 Year 2014 on Children Protection.

This problem can make children must deal with the law. Act No. 11 Year 2012 on the criminal justice system states that the definition of children having conflict with the law are namely a juvenile is the children whose age are 12 (twelve) years old, not 18 (eighteen) years old, and they are suspected to do the criminal offense.

Act No. 11 Year 2012 regarding Juvenile Justice System, provides a definition of children as follows:

- Article 1, point 3, theorized that children who is in conflict with the law hereinafter referred to as the child who is twelve (12) years old but under 18 (eighteen) years old and are suspected of criminal acts.

- Article 1, point 4, theorized that children who is a victim or referred to as child victims are children under 18 (eighteen) years old who is experiencing physical and mental suffering, and / or economic loss caused by the crime.

- Article 1, point 5 theorized that children who witness criminal acts, hereinafter referred to as child witness are children under 18 (eighteen) years old who can provide information for the purpose of investigation, prosecution and examination before the court on a criminal case which heard, seen and / or experienced by themselves. 
These children having conflict with the law need guidance and treatment, which name is penal mediation or in the juvenile justice system is namely a diversion. In this paper, there are two main problems; firstly, how is the penal mediation process in the juvenile justice system; secondly, how is the implementation of the penal mediation which is based on Pancasila?

\section{Method}

This paper used a normative juridical research method. The approach used in this study is socio legal approach (Samekto, 2012) which the law is conceptualized as a set of regulation that is valid in the society and the validity will be affected by other factors (economy, politic, culture, etc.). and The data types in this research include secondary data. The secondary data were obtained from the library research in order to get the theoretical basis in form of opinions, the writings from the experts or other authorized parties and to get the information in formal provision and data through the existing official manuscript. The secondary data were obtained from the valid legislation in Indonesia, book, seminar, journal, document, archive, and internet. The data analysis method used a qualitative analysis.

\section{Results and Discussion}

\section{Mediation in General}

Conflict resolution through mediation is a type of alternative conflict resolutions that has long been used to resolve various types of conflict (Wirawan, 2009). In Indonesia, mediation is used in conflict resolution across the indigenous peoples, families/marriages, and interpersonal conflicts, as well as the conflict resolution of business and government, the resolution of industrial relations disputes, and not to mention the social conflicts. Conflict resolution through mediation is a conflict management process in which the parties to the conflict settle their conflicts through negotiations to reach an agreement.

The objectives of the mediation conflict resolution process used by the parties to the conflict (Wirawan, 2009) are creating win \& win solution; focusing more on the future than in the past; control such as the parties to the conflict feel that they have more opportunities to control their own relationships and make their own decisions. While in court and arbitration proceedings, decisions 
are made by judges and arbiters instead of by the parties to the conflict; cost because the process is informal, flexible, and avoiding "legal process delays", mediation is cheaper than litigation and arbitration; faster resolution such as mediation process can be completed within days or weeks, unlike the times needed in court proceedings that can be months or even years; more options available such as in the mediation process, more choices and more creative and remedial solutions can be developed compared to courts and arbitration; flexible such as the mediation process is managed by mediators and parties to the conflict, and is not subject to procedural laws governed by law or a rigid arbitration process and seeking a satisfactory agreement together, mediation is not related to determining errors or inaccuracies, penalties from parties to the conflict.

\section{Diversion in The Juvenile Justice System.}

Maud A. Merril has defineted a juvenile is child is classified as a delinquent when his anti social tendencies appear to be so grave that become or ought to become the subject of official action. Juvenile delinquency is one of the most serious problems plaguing contemporary societies in different countries across the world. For decades, society has been seeking effective ways to address and resolve the issue, by developing different theories accounting for the progress of juvenile delinquency. One of the powerful factors related to the problem are child rearing practices applied by parents and approved by society. (Ehlemua, 2014)

In The Beijing Rules Rule 5.1, said "The juvenile justice system shall emphasize the well being of the juvenile and shall ensure that any reaction to juvenile offenders shall always be in proportion to the circumstances of both the offenders and the offence". In Commentary Rule 5.1. The Beijing Rules, Juvenile Justice system are to :

a. The promotion of the well being of the juvenile;

b. The principle of the proportionality.

In Black's Law Dictionary, Divertion is turning a side or altering the natural course or route of a thing. The term is chiefly applied to the an authorized change or alteration of the water course to the prejudice of a lower reparian, or the authorized use of fund (Black, 1990).

Since the 1970s, pre- and postcharge diversion programs have been used as a formal intervention strategy for youth offenders. (Holly A. Wilson, 2013) This meta-analysis was conducted to shed some light on whether diversion reduces recidivism at a greater rate than traditional justice system processing and to explore aspects of diversion programs associated with 
greater reductions in recidivism.

In Indonesia, Act No. 11 Year 2012 on the Juvenile Justice System brings newness with the diversion to achieve restorative justice. The characteristics of restorative Justice are (Maxwell, 2001):

a. Crime is primarily conflict between individuals resulting in injuries to vietims, communities and the offenders themselves; only secondary is it lawbreaking.

b. The overarching aim of the criminal justice process should be to reconcile parties while repairing the injuries caused by erimes.

c. The Criminal justice process should facilitate active participation by victims, ojfenders and their communities, It should not be dominated by goverment to the exclusion or others

Restorative justice is an alternative concept to solving a juvenile criminal in Indonesia. Howard Zehr stated that (Zehr, 1990)“ Restorative justice sees things differently...Crimes is a violation of people and relationships... It creates obligations to make things right. Justice involves the victim, the offender and the community in a search for solutions which promote repair, reconciliation, and reassurance".

There many various type of restorative justice in a juvenile justice process. There are (McIvor, 2004) :

1. Community service.

Community service was first introduced as a sentencing option in California in the 1960s. During the following two decades it was introduced in most western jurisdiction sand through out the United States and Canada. Community service was first made available in England and Wales in 1973 and in Scotland in 1977, where it proved to be a relatively popular sentencing option with the courts.

2. Victim-offender mediation and reparation.

Victim-offender mediation and reparation has its origins in Kitchener, Ontario and in the Mennonite movement aims to involve victims directly in the resolution of their offence. Skilled mediators facilitate an exchange between the victim and offender aimed at providing an explanation for the offence, enabling the offender to appreciate the impact of the offence on the victim and reaching an agreement as to the action to be taken by the offender to repair the harm.

3. Family Group Conferences. 
Family Group Conferences has seek to involve a wider constituency (including 'supporters' of both the victim and the offender) in discussion of the offence and decision-making about the actions to be undertaken by the offender to make amends. The origins of contemporary interest in conferencing lay in dissatisfaction, in New Zealand, with justice processes which offered little victim involvement and which often resulted in discriminatory outcomes for the Maori population. Recognition of these problems brought the legitimacy of traditional justice processes and their outcomes into question. Conferencing was seen as providing a mechanism both for involving victims more directly in the justice process and allowing Maoris to return to their own system of justice.

4. Circle Sentencing.

Circle Sentencing was first developed in the Yukon, Canada in 1991 before being extended to other parts of Canada and the USA. Circle Sentencing is based upon the traditional sanctioning and community healing processes of First Nation people in Canada and American Indians in the United States. The Circle may include, in addition to the offender and victim, family and friends of both, criminal justice and social services personnel, and interested members of the community. Speaking in turn through a symbolic 'talking piece', members of the Circle seek to gain an understanding of the offence and to identify how all the affected parties can be healed and further crimes prevented. Other reparative approaches include Community Panels of various types which have been established in a number of jurisdictions. These typically involve trained members of the community deciding on the course of action to be taken by the offender to make reparation for the offence.

In Canada in 1994, circles of support and accountability was introduced when a group of local people decided to provide assistance to a paedophile who was released back into their community. The model as evolved in Canada involves a professionally supported volunteer framework. High-risk sexual offenders who would not be subject to statutory supervision on release (the 'core members') are provided with support from and held accountable by a small number of volunteers who make contact with them on a daily basis and who hold weekly meetings to address any issues that may arise.

According to Act No. 11 Year 2012 on the Juvenile Justice System, Article 1 point 7, diversion is a transfer of the settlement of a Juvenile's case from the criminal justice process to the proceedings outside the criminal court. 
The arrangement of the diversion mentioned in Act No. 11 Year 2012 on Juvenile Justice System Article 6 states that the diversion aims to achieve peace between the victim and the juvenile; resolve cases of juvenile outside the judicial process; prevent the juvenile from deprivation of liberty; encourage people to participate; and instill a sense of responsibility to the juvenile.

The diversion process is carried out through discussion by involving the juvenile and their parents/custodian, victims and/or parents/custodian, Community Guides, and Professional Social Workers based on the Restorative Justice approach. The diversion process should also pay attention to:
a. the interests of victims;
b. welfare and responsibility of the juvenile;
c. avoidance of negative stigma;
d. avoidance of retaliation;
e. community harmony; and
f. propriety, decency, and public order.

Law enforcement officers, investigators, prosecutors, and judges in doing diversions should consider:

a. category of crime;

b. age of juvenile;

c. results of community investigation from correctional institution; and

d. support from the family and community environment.

To reach diversion agreement, the approval of victim and/or family of child victim and willingness of child and family must be accepted. The Diversion Agreement conducted by the Investigator upon the recommendation of a Community Guidance may take the following forms:

a. indemnification if there is a victim;

b. medical and psychosocial rehabilitation;

c. handover to parent/custodian;

d. participation in education or training in educational institution no longer than 3 months; or

e. public service no longer than 3 months.

The results of diversion agreement can be:

a. peace with or without indemnification; 
b. handover to parent/guardian;

c. participation in education or training in educational institution no longer than 3 months; or

d. community service.

The implementation of diversion at every stage of law enforcement:

1. Investigation

a. The investigator must endeavor diversion no longer than 7 days after the investigation began.

b. The diversion process must be conducted no later than 30 days after the diversion began

c. If the diversion process reaches an agreement, the investigator delivers the Diversion Record along with Diversion Agreement to the chairman of the district court to make the determination.

d. If the diversion process fails, the investigator is required to continue the investigation and to transfer the case to the public prosecutor to attach Diversion Record and community investigation reports.

2. Prosecution

a. Public Prosecutor should endeavor Diversion no later than 7 days after receiving the dossier from the Investigator.

b. Diversion is conducted no longer than 30 days.

c. If the Diversion process reaches an agreement, the public prosecutor delivers the Diversion record along with Diversion agreement to the chairman of the district court to make the determination.

d. If the Diversion process fails, the public prosecutor is required to submit the Diversion record and transferred to the court to attach social investigation reports.

\section{Examination in Court}

a. The chairman of the court should decide a judge or a panel of judges to hold court session for the juvenile cases at least 3 days after receiving the case file from the public prosecutor.

b. The judges must endeavor the diversion no longer than 7 days after stipulated by the chairman of the district court as a judge.

c. The Diversion process will be no longer than 30 days.

d. The Diversity process can be implemented in the mediation room of the district court. 
e. If the Diversion process reaches an agreement, the judge delivers Diversion record along with Diversion agreement to the chairman of the district court to make the determination.

f.Conversely, if the Diversion process fails, the case proceeds to court trial.

The Diversion process involves the structure of the apparatus i.e. the Community Counselor. According to Article 65, the Community Counselor are responsible to:

a. Make a report of community investigation for the interest of Diversion, perform counseling, guidance and supervision of the juvenile during the Diversion process and the implementation of the agreement, including to report to the court if Diversion is not implemented;

b. make a report of community investigation for the interest of investigation, prosecution and trial of juvenile cases, both inside and outside the session, including in Juvenile Correctional Institution;

c. determine the juvenile care programs and coaching at Juvenile Correctional Institution along with other correctional officers;

d. perform counseling, guidance and supervision of juvenile who are under the verdict of court are subject to action and;

e. perform counseling, guidance and supervision of juvenile who are assimilated, parole, free leave, and conditional leave.

There are some resistor factors in the diversion in the juvenile justice system in Indonesia, which are :

1) The policy of prosecution formulas and inspection formulas of the juvenile court in the juvenile justice system are implemented diversion;

2) Law enforcer in the juvenile justice system criminal still jetty to retaliation target in the law enforcement to deed of the juvenile;

3) Law enforcer still place the institute interest than to protect the child in the implementation of the juvenile justice system;

4) Law enforcer will remain to continue the inspection and prosecution in the court if there are no parties for example such as LSM applying to stop inspection, and particularly if the juvenile child have already in the detention;

5) The knowledge of law enforcer concerning with diversion in the juvenile justice system still very less

6) The supporter of diversion program in Indonesia still very less, either through the 
institution and the facility.

Restorative Justice is the settlement of criminal cases involving perpetrators, victims, families of perpetrators/victims, and other parties concerned to jointly seek a fair settlement by emphasizing restoration back to the previous state, rather than retaliation.

Based on comparative law, penal mediation in the juvenile deliquency in Albania are education or re-education. In Albania (Cerekja, 2014), the mediator gives room to conduct negotiations in criminal matters. Though, the scope of application of penal mediation, not only in Albania but beyond, is unfortunately limited to a restricted number of provisions, mainly referring to criminal contraventions. For instance, mediation is possible in cases of criminal offences related to bodily injuries, injury due to negligence, violation of domicile or cafés and so on but we will dwell on this topic latter while the Albanian legislation in the field of mediation will be analyzed. In all these cases and featuring a key characteristic of this Institute is the fact that mediation is not compulsory. Judicial authorities and all other operators of the justice system cannot force the victims or perpetrators of offences to consent to mediation procedure. This may occur in no case. The victims and perpetrators may and should jointly decide to initiate the mediation procedure, referring to the mediator or mediators. In respect of juveniles, as equally applied in the criminal and criminal procedural legislation, the organic law on mediation provides all necessary safeguards provided for in the domestic and international legislation (Paragraph No. 12 of Recommendation No. R (99) 19 of the Committee of Ministers addressed to the member states in respect of mediation in criminal matters (Approved by the Committee of Ministers on 15 September 1999 in the 697th meeting of the deputy ministers).

The principle of confidentiality is another typical and core element for the functioning of mediation procedure, particularly in reference to cases of juvenile perpetrators or victims. This principle is translated to the confidentiality of not only cases/facts of concrete circumstances of cases but also the results drawn during the mediation process.

\section{Implementation of Penal Mediation which is Based on Pancasila}

Renewal of penal mediation can be regarded as a reform of criminal law. Barda Nawawi Arief stated (Arief, 2008) "... the meaning and essence of criminal law reform (penal reform) is closely related to the background and the urgency of holding criminal law reform itself. In essence, 
(criminal) law reform implies an attempt to reorient and reform criminal laws in accordance with the central values of socio-politics, socio-philosophy, socio-culture, socio-policy of Indonesian society, criminal policy, and law enforcement policy in Indonesia. In short, it can be said that the reform of criminal law must be essentially taken with the policy oriented approach and at the same time with the value-oriented approach".

The philosophical value of the Indonesian Nation is Pancasila. The embodiment of Pancasila values is contained in each pillar namely: Belief in the one supreme God, Justice and Civilized Humanity, The Unity of Indonesia, The Democracy Led by Understanding Wisdom among Honorable Representative, from the Parliament House, and Social Justice for All of the People of Indonesian. The realization of Pancasila values becomes the standard of ethical values of Indonesian society. The ethics of Indonesian society are based on the principles of Pancasila; therefore, the people of Indonesia are said to be (Sunoto, 1989) religious society; humanist society; an intact and united society; kinship society; and just society.

According that, penal mediation or diversion in juvenile justice system are relevant with the social-philosophic which is Pancasila, because the idea of, diversion is not against the ethic in the society, ideology and moral of Indonesian society; diversion are relevent in Indonesia because diversion have the programs such as : warning and sending the children to the parents or guidance, restitution, counseling, controlling, social work, as a tool of protecting children as stated in the national goal that is protecting the society and give prosperity condition for the children (juvenile).

According that, the settlement can be conducted if there are circumstances condition in the juvenile cases that was diversion or penal mediation such as:

1) condition of the children that still young.

2) the children still need school;

3) the parents and guardian that able to guide;

4) light punishment;

5) the victim apologies and accept the restitution;

6) environmental condition that proper to guide those children;

7) the juvenile not necessary to arrest;

8) the juvenile are not the recidivist. 


\section{Conclusion}

Based on the explanation above, it can be concluded as follows:

1. The diversion process in Indonesia was at in Act No. 11 Year 2012 on juvenile justice system. Diversion process to promote restorative justice which aims to achieve peace between the victim and the juvenile; resolve cases of juvenile outside the judicial process; prevent the juvenile from deprivation of liberty; encourage people to participate; and instill a sense of responsibility to the juvenile. Based on restorative justice process, there are various type of a restorative justice process are There many various type of restorative justice in a juvenile justice process. There are Community service, Victim-offender mediation and reparation, Family Group Conferences and Circle Sentencing.

2. Penal mediation or diversion process in Indonesia isbased on Pancasila as the philosophical foundation of Indonesia, which means diversion programs must be in accordance with the values of Pancasila, such as warning and sending the children to the parents or guidance, restitution, counseling, controlling, social work, as a tool of protecting children as stated in the national goal that is protecting the society and give prosperity condition for juvenile to become the best interest of the child.

\section{References}

Black, Henry Campbell. (1990). Black's Law Dictionary ( Sixth Edition). St. Paul Minn :West Publicing Co, page 477.

Cerekja, Besnik. (2014). Penal Mediation in The Framework of Juvenile Delinquency in Albania : Education or Re-education, Academic Journal of Interdiciplinary Studies Vol. 3 No. 6 Tahun 2014.

Ehiemua, Solomon. (2014). Juvenile Delinquency : A Comparative Stucy Between Child Rearing Practices in Developed and Developing Countries. European Jurnal of Research in Social Sciences Vol. 2 No.4. 2014.

Maxwell, Gabrielle and Allison Morris. (2001). Restorative Justice For Juveniles Conference Mediation and Circles. USA: Hart Publishing.

McIvor, Gill. (2004). Alternative to Prison Options for an Insecure Society, Reparative and Restorative Approaches. USA and Canada : Willan Publishing, page 162-164. 
Nawawi Arief, Barda. (2008). Bunga Rampai Kebijakan Hukum Pidana Perkembangan Penyusunan Konsep KUHP Baru. Jakarta: Kencana Prenada Media Group, page 25.

Samekto, FX. Adji. (2012). Ilmu Hukum Dalam Perkembangan Pemikiran Menuju PostModernisme. Bandar Lampung : Indept Publishing, 2012, page 61-62.

Sunoto. (1989). Filsafat Sosial dan Politik Pancasila, Edisi Ketiga. Yogyakarta : Andi Offset, page 49-53.

Wilson, Holly A. and Robert D. Hoge. (2013). The Effect of Youth Diversion Programs on Recidivism A Meta Analytic Review, SAGE Journals Vol. 40, Issue Published May, 1, 2013.

Wirawan. (2009). Konflik dan Manajemen Konflik. Teori, Aplikasi, dan Penelitian. Jakarta: Salemba Humanika, page 200.

Zehr, Howard. (1990). Changing Lenses : A New Focus for Crime and Justice. Pensylvania, Herald Press Scottdale, page 182. 